Jurnal Akuntansi dan Manajemen

Vol.15, No.2, 2020, Hal.16-26

\title{
Hubungan Antara Penerapan Good Corporate Governance (GCG) dengan Risiko Financial Perbankan
}

\author{
Dita Maretha Rissi ${ }^{1}$, Lisa Amelia Herman ${ }^{2}$ \\ 1Jurusan Akuntansi, Politeknik Negeri Padang \\ Email: ditamaretharissi@gmail.com \\ ${ }^{2}$ Jurusan Akuntansi, Politeknik Negeri Padang \\ Email: lisa.ameliaherman@gmail.com
}

\begin{abstract}
This research is a quantitative study. The purpose of this study was to determine the relationship between the implementation of good corporate governance (GCG) and the financial risk of banking at Bank Nagari, starting from 2015-2019. In the principles of good corporate governance (GCG), there are principles of transparancy, accountability, responsibility, independence and fairness. This research is built on the belief that by implementing GCG in Bank Nagari, the Bank has a strong internal management and can automatically minimize financial risks that can harm Bank Nagari. The data collection methods used in this study were interviews and documentary studies conducted at the Compliance Work Unit and the Risk Management Division at Bank Nagari, Padang Head Office. The data obtained were analyzed using the Spearman Rank Correlation method. The results of this study indicate that there is a very strong relationship between the implementation of good corporate governance (GCG) and banking financial risk at Bank Nagari, where the implementation of good GCG principles is believed to strengthen the internal conditions of Bank Nagari effectively and efficiently as well as financial risk. minimized. In addition, the research results also show that the motivation of Bank Nagari in implementing GCG from 2015-2019 is getting better based on the results of self-assessments that are conducted annually.

Keywords: good corporate governance, financial risk
\end{abstract}

\begin{abstract}
Abstrak
Penelitian ini merupakan sebuah penelitian kuantitatif. Tujuan dari penelitian ini adalah mengetahui hubungan antara penerapan good corporate governance (GCG) dengan risiko finansial perbankan pada Bank Nagari yang dimulai dari tahun 2015-2019. Pada prinsip tata kelola perusahaan yang baik (GCG) didalamnya terdapat prinsip keterbukaan, akuntabilitas, tanggung jawab, indepedensi, dan kewajaran. Penelitian ini dibangun pada keyakinan bahwa dengan diterapkannya GCG pada Bank Nagari maka Bank tersebut memiliki pengelolaan internal yang kuat dan secara otomatis dapat meminimalisir risiko finansial yang dapat merugikan Bank Nagari. Metode pengumpulan data yang digunakan dalam penelitian ini adalah wawancara dan studi dokumenter yang dilakukan pada bagian Satuan Kerja Kepatuhan dan Divisi Managemen Risiko pada Bank Nagari Kantor Pusat Padang. Data yang diperoleh dianalisis menggunakan metode Korelasi Rank Spearman. Hasil penelitian ini menunjukan bahwa adanya hubungan yang sangat kuat antara penerapan good corporate governance (GCG) dengan risiko finansial perbankan pada Bank Nagari, dimana dengan diterapkannnya prinsip-prinsip GCG dengan baik diyakini akan memperkuat kondisi internal Bank Nagari secara efektif dan efisien serta risiko finansial dapat diminimalisir. Selain itu hasil penelitian juga memperlihatkan bahwa motivasi Bank Nagari dalam penerapan GCG dari tahun 2015-2019 semakin membaik berdasarkan hasil self assessment yang dilakukan setiap tahunnya.
\end{abstract}

Kata kunci: good corporate governance (GCG), risiko financial perbankan 


\section{PENDAHULUAN}

Arsitektur Perbankan Indonesia (API) merupakan suatu kerangka dasar sistem perbankan Indonesia yang bersifat menyeluruh dan memberikan arahan, bentuk dan tatanan industri perbankan untuk rentang waktu lima sampai sepuluh tahun ke depan. Di dalamnya terdapat enam pilar utama yang merupakan sasaran yang ingin dicapai, salah satunya adalah menciptakan good corporate governance untuk memperkuat kondisi internal perbankan nasional. Tidak hanya berhenti sampai disitu, untuk menunjukkan keseriusan terhadap isu good corporate governance (GCG), maka pada tanggal 30 Januari 2010 Bank Indonesia (BI) mengeluarkan paket kebijakan perbankan yang dikenal dengan istilah Pakjan 2010 mengenai peraturan baru tentang pelaksanaan good corporate governance. Pelaksanaan good corporate governance (GCG) tersebut diimplementasikan melalui Peraturan Bank Indonesia Nomor 8/14/PBI/2006 tentang pelaksanaan good corporate governance (GCG) bagi bank umum. Dalam PBI Nomor 8/14/PBI/2006 dinyatakan bahwa setiap bank harus membuat self assessment atas penerapan good corporate governance (GCG). Self assessment akan dinilai setiap akhir tahun untuk melihat apakah good corporate governance (GCG) sudah dilaksanakan dengan baik atau belum.

Beberapa peraturan yang telah dikeluarkan berkaitan dengan penerapan prinsip GCG antara lain adalah Peraturan Bank Indonesia No.2/27/PBI/2000 tanggal 15 Desember 2000 tentang bank umum. Ketentuan tersebut mengatur kriteria yang wajib dipenuhi oleh calon anggota Direksi dan Komisaris serta batasan transaksi yang diperbolehkan atau dilarang oleh pengurus bank. Peraturan lainnya yang dikeluarkan berkaitan dengan kebutuhan peningkatan GCG adalah PBI No.5/8/PBI/2003 tentang penerapan manajemen risiko bagi Bank Umum yang selanjutnya ditindaklanjuti dengan diterbitkannya SE No.5/21/DPNP tanggal 29 September 2003. PBI tersebut mewajibkan bank untuk menetapkan wewenang dan tanggung jawab yang jelas pada setiap jenjang jabatan yang terkait dengan penerapan manajemen risiko.

Penerapan good corporate governance (GCG) ini dinilai dapat memperbaiki citra perbankan yang sempat buruk, melindungi kepentingan stakeholders serta meningkatkan kepatuhan terhadap peraturan perundang-undangan yang berlaku dan etika-etika umum pada industri perbankan. Selain itu penerapan good corporate governance dalam dunia perbankan dapat mengurangi agency cost, dimana biaya ini harus ditanggung pemegang saham akibat pendelegasian wewenang kepada pihak manajemen. Biaya-biaya ini dapat berupa kerugian yang diderita bank sebagai akibat penyalahgunaan wewenang ataupun berupa biaya pengawasan yang timbul untuk mencegah terjadinya hal tersebut.

Dengan menerapkan teknik dan strategi GCG tersebut secara tidak langsung bank dapat meminimalisir risiko perbankan yang akan muncul nantinya. Risiko yang mungkin terjadi dapat menimbulkan kerugian bagi bank jika tidak dideteksi dan tidak dikelola sebagaimana mestinya. Bagi manajer bank dan seluruh pihak yang terkait harus mengetahui bagaimana dan kapan risiko akan muncul, sehingga bank dapat mengantisipasi dan mengambil keputusan yang tepat. Untuk itu, bank harus mengerti dan mengenal risiko-risiko yang mungkin muncul dalam melaksanakan kegiatan usahanya.

Pada dasarnya jenis-jenis risiko yang dihadapi bank terbagi atas dua kelompok yaitu risiko finansial yang memiliki 4 (empat) indikator pengukuran yaitu risiko kredit, risiko pasar, risiko operasional, risiko likuiditas dan risiko nonfinansial juga memiliki 4 (empat) indikator pengukuran seperti risiko kepatuhan, risiko hukum, risiko reputasi, risiko strategis. Risiko finansial terkait dengan kerugian berupa hilangnya sejumlah uang akibat risiko yang terjadi. Di sisi lain, risiko nonfinansial terkait kepada kerugian yang tidak dapat dikalkulasikan secara jelas jumlah uang yang hilang. Salah satu bentuk risiko nonfinanasial adalah kasus seperti kehilangan nasabah dan kehilangan bisnis akan mengakibatkan bank menjadi rugi (Idroes, 2016: 23).

Untuk menjaga konsistensi dan kontinuitas, bank seharusnya mampu mengelola risiko-risiko perbankan khususnya dalam pengelolaan risiko finansial agar dampak negatif tidak terjadi. Menurut 
Idroes (2016: 23). Dengan berbagai risiko tersebut, bank dituntut melakukan manajemen risiko seefektifitas mungkin agar likuiditas bank tetap terjaga sehingga bank tidak mengalami kesulitan dalam memenuhi kebutuhan jangka pendeknya. Dengan kata lain risiko finansial bersifat kuantitatif dalam proses pengukuran sedangkan risiko nonfinansial bersifat kualitatif, oleh karena itu penulis lebih memfokuskan dalam penelitian ini menggunakan risiko finansial karena lebih terukur dibanding risiko nonfinansial.

Bank Nagari merupakan satu-satunya entitas yang dimiliki Sumatera Barat. Saat ini asset kelolaan yang dimiliki oleh Bank Nagari telah mencapai Rp 24,4 triliun (posisi Desember 2019). Pada hakekatnya Bank Nagari juga memiliki muatan agent of development. Artinya harus disadari bahwa Bank Nagari tidak hanya pure entitas bisnis, namun terkandung muatan mempunyai kewajiban ikut mendorong percepatan pertumbuhan ekonomi di Sumatera Barat. Berdasarkan pemahaman tersebut, Bank Nagari melakukuan terobosan mengenai konsep regional champion yang tidak lari dari konsep dasarnya. Konsep Bank Nagari ditargetkan menjadi regional champion dengan tiga parameter yaitu ketahanan kelembagaan, berperan sebagai agen pembangunan dan peningkatan pelayanan masyarakat. Pada hal ini sejalan dengan konsep dasar yang disusun oleh Bank Indonesia yang bertumpu kepada dua aspek yakni penerapan good corporate governance dan manajemen risiko.

Berdasarkan uraian di atas, penulis tertarik untuk mengangkat dan menganalisis masalah tersebut dengan melakukan penelitian yang berjudul "Hubungan antara Penerapan Good Corporate Governance (GCG) dengan Risiko Finansial Perbankan" (Studi Kasus pada Bank Nagari Kantor Pusat Padang).

\section{LANDASAN TEORI}

\section{Teori Agency (Agency Theory)}

Dalam perekonomian modern, manajemen dan pengelolaan perusahaan semakin banyak dipisahkan dari kepemilikan perusahaan. Hal ini sejalan dengan Agency Theory yang menekankan pentingnya pemilik perusahaan (pemegang saham) menyerahkan pengelolaan perusahaan kepada tenaga-tenaga professional (disebut agents) yang lebih mengerti dalam menjalankan bisnis seharihari. Tujuan dari dipisahkannya pengelolaan dari kepemilikan perusahaan yaitu agar pemilik perusahaan memperoleh keuntungan yang maksimal dengan biaya yang seefesien mungkin dengan dikelolanya perusahaan oleh tenaga-tenaga professional. Tenaga professional bertugas untuk kepentingan perusahaan dan memiliki keleluasaan dalam menjalankan manajemen perusahaan sehingga dalam hal ini para professional tersebut berperan sebagai agents pemegang saham. Semakin besar perusahaan memperoleh laba, maka semakin besar pula keuntungan yang diperoleh agents. Sementara pemilik perusahaan (pemegang saham) hanya bertugas mengawasi dan memonitor jalannya perusahaan yang dikelola oleh manajemen. (Harahan, 2011:111)

\section{Good Corporate Governance (GCG)}

Konsep good corporate governance (GCG) menjadi bagian yang sering didiskusikan dengan tujuan agar para pihak mampu memahami manfaat atau dampak positif dari penerapan konsep tersebut. Salah satu maksud dan tujuan dari good corporate governance (GCG) adalah mengharapkan berbagai perusahaan yang berada di suatu Negara mampu menjalankan aktivitas bisnis secara baik dan ikut serta dalam mendorong pertumbuhan ekonomi nasional yang beretika tinggi. Adapun prinsip-prinsip dari good corporate governance adalah sebagai berikut:

a. Transparency (Keterbukaan Informasi)

Secara sederhana bisa diartikan sebagai keterbukaan informasi. Dalam mewujudkan prinsip ini, perusahaan dituntut untuk menyediakan informasi yang cukup, akurat, tepat waktu kepada segenap stakeholder. 
b. Accountability (Akuntabilitas)

Yang dimaksud dengan akuntabilitas adalah kejelasan fungsi, struktur, sistem, dan pertanggungjawaban elemen perusahaan.

c. Responsibility (Pertanggungjawaban)

Bentuk pertanggung jawaban perusahaan adalah kepatuhan perusahaan terhadap peraturan yang berlaku diantaranya adalah masalah pajak, hubungan industrial, kesehatan dan keselamatan kerja, perlindungan lingkungan hidup, memelihara lingkungan bisnis yang kondusif bersama masyarakat dan sebagainya.

d. Indepedency (Kemandirian)

Prinsip ini mensyaratkan agar perusahaan dikelola secara profesional tanpa ada benturan kepentingan dan tanpa tekanan atau intervensi dari pihak manapun yang tidak sesuai dengan peraturan-peraturan yang berlaku. Dengan kata lain, prinsip ini menuntut bertindak secara mandiri sesuai peran dan fungsi yang dimilikinya tanpa ada tekanan.

e. Fairness (Kesetaraan dan Kewajaran)

Prinsip ini menuntut adanya perlakuan yang adil dalam memenuhi hak stakeholders sesuai dengan peraturan perundangan yang berlaku. Diharapkan fairness dapat menjadi faktor pendorong yang dapat memonitor dan memberikan jaminan perlakuan yang adil di antara beragam kepentingan dalam perusahaan.

\section{Risiko Financial Perbankan}

Dekade ini industri perbankan Indonesia dihadapkan dengan risiko yang semakin kompleks akibat kegiatan usaha bank yang beragam mengalami perkembangan pesat sehingga mewajibkan baik untuk meningkatkan kebutuhan akan penerapan manajemen risiko untuk meminimalisasi risiko yang terkait dengan kegiatan usaha perbankan. Implementasi manajemen risiko yang bank di Indonesia diarahkan sejalan dengan standar baru secara global yang dikeluarkan oleh Bankfor Internasional Settlement (BIS) sebagaimana diadopsi oleh Bank Indonesia melalui peraturan Nomor 5/8/PBI/2003 tentang penerapan Manajemen Risiko bagi Bank Umum agar perbankan Indonesia dapat beroperasi secara lebih berhati-hati dan penerapannya disesuaikan dengan tujuan, kebijakan usaha, ukuran dan kompleksitas usaha serta kemampuan bank dalam hal keuangan, infrastruktur pendukung maupun sumber daya manusia. Dengan ketentuan ini, bank diharapkan mampu melaksanakan seluruh aktivitasnya secara terintegritas dalam suatu system pengelolaan risiko yang akurat dan komprehensif (Sari, 2017: 1). 


\section{KERANGKA BERPIKIR}

Kerangka berpikir penelitian ini dapat digambarkan sebagai berikut:

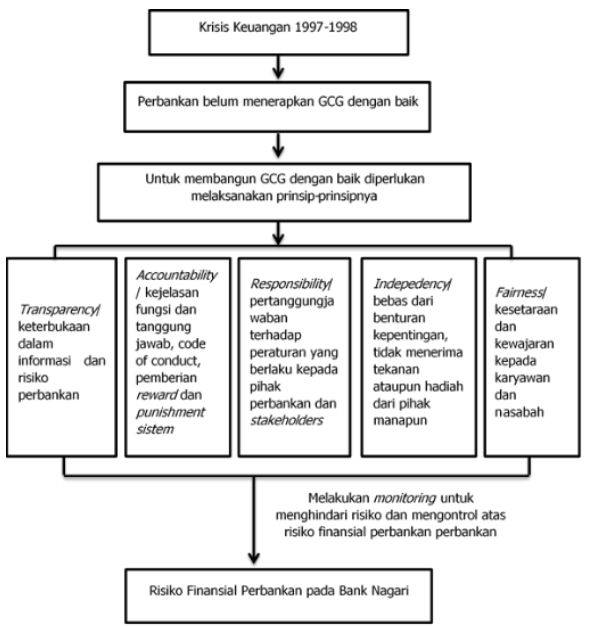

Gambar 1: Kerangka Berpikir

\section{PENGEMBANGAN HIPOTESIS}

Hipotesis penelitian yang diajukan adalah sebagai berikut:

Ho: Tidak ada hubungan antara penerapan GCG dengan risiko finansial.

Ha: Ada hubungan antara penerapan GCG dengan risiko risiko finansial.

\section{METODOLOGI PENELITIAN}

Desain Penelitian ini menggunakan pendekatan kuantitatif dengan hubungan korelasi. Penelitian ini meneliti hubungan variabel penerapan good corporate governance (GCG) dengan risiko financial perbankan pada Bank Nagari Kantor Pusat Padang. Penelitian ini dilakukan pada Bank Nagari Kantor Pusat. Alasan pemilihan lokasi penelitian ini adalah:

1. Bank Nagari merupakan bank konvensional yang memiliki kompleksitas tinggi.

2. Bank Nagari memiliki muatan yang besar untuk mendorong percepatan ekonomi di Sumatera Barat.

3. Bank Nagari memiliki kinerja baik berdasarkan peringkat bank daerah diseluruh Indonesia. Definisi operasional variabel pada penelitian ini dapat diringkas pada tabel dibawah:

Tabel 1. Definisi Operasional dan Pengukuran Variabel

\begin{tabular}{|l|l|l|l|}
\hline \multicolumn{1}{|c|}{ Variabel } & \multicolumn{1}{|c|}{ Indikator } & \multicolumn{1}{c|}{ Skala } & \multicolumn{1}{c|}{ Sumber } \\
\hline GCG & $\begin{array}{l}11 \text { Indikator yang telah } \\
\text { ditetapkan oleh Bank } \\
\text { Indonesia No.9/12/DPNP. }\end{array}$ & Ordinal & $\begin{array}{l}\text { Laporan Tahunan } \\
\text { Bank Nagari } \\
\text { Tahun 2015-2019. }\end{array}$ \\
$\begin{array}{l}\text { Risiko Finansial } \\
\text { Perbankan }\end{array}$ & $\begin{array}{l}\text { Risiko kredit, risiko pasar, } \\
\text { risiko likuiditas dan risiko } \\
\text { operasional. }\end{array}$ & Interval & $\begin{array}{l}\text { Laporan Profil } \\
\text { Risiko Bank Nagari } \\
\text { Tahun 2015-2019. }\end{array}$ \\
\hline
\end{tabular}

Jenis data dalam penelitian ini adalah data sekunder. Data sekunder pada penelitian ini adalah annual report atau laporan keuangan tahunan dan profile risiko perbankan tahun 2015-2019. Teknik 
pengumpulan data pada penelitian ini menggunakan studi dokumentasi. Studi dokumentasi dilakukan pada penelitian ini bertujuan untuk memperoleh skor GCG dari masing-masing indicator risiko financial perbankan.

Metode analisis data pada penelitian ini menggunakan pengujian hipotesis statistic. Pengujian hipotesis pada penelitian ini menggunakan analisis koefisien korelasi urutan Spearman (The Rank Spearman). Pengujian korelasi urutan Spearman dikemukakan oleh Carl Spearman pada tahun 1904. Metode tersebut digunakan untuk mengukur keeratan hubungan antara dua variabel atau data ordinal. Kedua variabel itu tidak memiliki distribusi normal dan kondisi varians tidak diketahui sama. Selain itu dalam penelitian ini juga dilakukan pengujian signifikansi dengan dua sisi (two tailed) untuk mengetahui apakah terdapat hubungan signifikan atau tidak antar variabel tersebut dengan kriteria pengujian yaitu tingkat kepercayaan 95\% dan nilai signifikan $<0,05$. Koefisien korelasi urutan Spearman dirumuskan sebagai berikut: (Hasan, 2016: 307).

$r_{s}=1-\frac{6-\Sigma d^{2}}{n\left(n^{2}-1\right)}$

Keterangan :

$\mathrm{d}=$ beda urutan dalam satu pasangan data

$\mathrm{n}=$ banyaknya pasangan data

Koefisien korelasi merupakan indeks atau bilangan yang digunakan untuk mengukur keeratan (kuat, lemah atau tidak ada) hubungan antarvariabel. Koefisien Korelasi (KK) ini memiliki nilai antara -1 dan $+1(-1 \leq \mathrm{KK} \leq+1)$.

1. Jika KK bernilai positif, maka variabel-variabel berkorelasi positif. Semakin dekat nilai KK ini ke +1 semakin kuat korelasinya, demikian pula sebaliknya.

2. Jika KK bernilai negatif, maka variabel-variabel berkorelasi negatif. Semakin dekat nilai KK ini ke -1 semakin kuat korelasinya, demikian pula sebaliknya.

3. Jika KK bernilai 0 (nol), maka variabel-variabel tidak menunjukan korelasi.

4. Jika KK bernilai +1 atau -1 , maka variabel menunjukan korelasi positif atau negatif yang sempurna.

Untuk menentukan keeratan hubungan/korelasi antarvariabel tersebut, berikut ini diberikan nilai-nilai dari KK sebagai patokan:

a. $\mathrm{KK}=0$, Tidak ada korelasi.

b. $0<\mathrm{KK} \leq 0,20$, Korelasi sangat rendah/lemah sekali.

c. $0,20<\mathrm{KK} \leq 0,40$, Korelasi rendah/lemah tapi pasti.

d. $0,40<\mathrm{KK} \leq 0,70$, Korelasi yang cukup berarti.

e. $0,70<\mathrm{KK} \leq 0,90$, Korelasi yang tinggi/kuat.

f. $\quad 0,90<\mathrm{KK}<1,00$, Korelasi sangat tinggi; kuat sekali; dapat diandalkan.

g. $\mathrm{KK}=1$, Korelasi sempurna.

Langkah pengujian uji korelasi menggunakan Rank Spearman adalah dengan cara menetukan hipotesis dan kriteria pengujian serta penarikan kesimpulan dari hasil yang diperoleh. Langkah tersebut adalah sebagai berikut:

1. Penentuan Hipotesis

Ho: Tidak ada hubungan antara penerapan GCG dengan Risiko Finansial Perbankan. Ha: Ada hubungan antara penerapan GCG dengan Risiko Finansial Perbankan.

2. Kriteria Pengujian Jika Signifikan > 0,05, maka Ho diterima. Jika Signifikan $<0,05$, maka Ho ditolak.

3. Penarikan kesimpulan 
HASIL PENELITIAN DAN PEMBAHASAN

Adapun hasil dan pembahasan dari penelitian ini adalah sebagai berikut:

Tabel 2. Score GCG Bank Nagari Tahun 2015-2019

\begin{tabular}{|c|c|c|c|c|c|c|}
\hline \multirow[t]{2}{*}{ Aspek Yang Dinilai } & \multirow{2}{*}{$\begin{array}{l}\text { Bobot } \\
\%\end{array}$} & \multicolumn{5}{|c|}{ Tahun } \\
\hline & & 2015 & 2016 & 2017 & 2018 & 2019 \\
\hline $\begin{array}{l}\text { 1. Pelaksanaan tugas \& tanggung } \\
\text { jawab dewan komisaris }\end{array}$ & $10 \%$ & 0,2 & 0,1 & 0,2 & 0,2 & 0,2 \\
\hline $\begin{array}{l}\text { 2. Pelaksanaan tugas \& tanggung } \\
\text { jawab direksi }\end{array}$ & $20 \%$ & 0,4 & 0,4 & 0,4 & 0,4 & 0,4 \\
\hline $\begin{array}{l}\text { 3. Kelengkapan dan pelaksanaan } \\
\text { tugas komitte }\end{array}$ & $10 \%$ & 0,2 & 0,1 & 0,2 & 0,2 & 0,2 \\
\hline $\begin{array}{ll}\text { 4. } & \begin{array}{l}\text { Penanganan } \\
\text { kepentingan }\end{array} \\
\end{array}$ & $10 \%$ & 0,3 & 0,2 & 0,2 & 0,2 & 0,3 \\
\hline $\begin{array}{l}\text { 5. Penerapan fungsi kepatuhan } \\
\text { bank }\end{array}$ & $5 \%$ & 0,1 & 0,1 & 0,1 & 0,1 & 0,1 \\
\hline 6. Penerapan fungsi audit intern & $5 \%$ & 0,1 & 0,1 & 0,1 & 0,1 & 0,1 \\
\hline $\begin{array}{lll}\text { 7. Penerapan fungsi } & \text { audit } \\
\text { eksteren }\end{array}$ & $5 \%$ & 0,05 & 0,05 & 0,05 & 0,05 & 0,05 \\
\hline $\begin{array}{l}\text { 8. Penerapan fungsi managemen } \\
\text { risiko \& pengendalian intern }\end{array}$ & $7,5 \%$ & 0,15 & 0,15 & 0,15 & 0,15 & 0,15 \\
\hline $\begin{array}{l}\text { 9. Penyediaan dana kepada pihak } \\
\text { terkait }\end{array}$ & $7,5 \%$ & 0,075 & 0,075 & 0,075 & 0,075 & 0,15 \\
\hline $\begin{array}{l}\text { 10. Transparansi kondisi } \\
\text { keuangan dan non keuangan } \\
\text { laporan pelaksanaan GCG }\end{array}$ & $15 \%$ & 0,3 & 0,15 & 0,3 & 0,3 & 0,3 \\
\hline 11. Rencana strategis bank & $5 \%$ & 0,1 & 0,1 & 0,1 & 0,05 & 0,05 \\
\hline Total & $100 \%$ & 1,975 & 1,525 & 1,875 & 1,825 & 2,00 \\
\hline
\end{tabular}

Sumber: Data Sekunder Bank Nagari Tahun 2015-2019

Keterangan:

1. Nilai Komposit $<1,5=$ Sangat Baik

2. $1,5<$ Nilai Komposit $<2,5=$ Baik

3. $2,5<$ Nilai Komposit $<3,5=$ Cukup Baik

4. $3,5<$ Nilai Komposit $<4,5=$ Kurang Baik

5. $>4,5$

= Tidak Baik

Sumber: SE No.9/12/DPNP/2007

Berdasarkan tabel 2 di atas terdapat data yang digunakan dalam penelitian ini. Tabel tersebut mencerminkan self assesment GCG yang dilakukan oleh Bank Nagari mulai dari tahun 2015-2019 terhadap 11 indikator sebagaimana yang sudah diuraikan pada bab terdahulu. Pelaksanaan GCG pada tahun 2015 merupakan tahun kedelapan bagi Bank Nagari untuk melaksanaan GCG sebagaimana yang diharapkan oleh Bank Indonesia. Skor GCG diperoleh dengan cara mengalikan peringkat dengan bobot, sehingga dapat dijumlahkan hasil dari masing-masing indikator tersebut. Pada tahun 2015 Bank Nagari memperoleh skor 1,975 dimana skor tersebut menduduki peringkat Baik. Berdasarkan informasi yang diperoleh dari kesimpulan GCG pada Bank Nagari tahun 2015, skor GCG mengalami penurunan dibandingkan dengan skor tahun sebelumnya. Dengan adanya 
penurunan skor tersebut berarti penerapan GCG pada Bank Nagari semakin baik. Dari uraian di atas, dapat disimpulkan bahwa selama 5 (lima) tahun terakhir penerapan atau pelaksanaan GCG pada Bank Nagari berjalan dengan baik meskipun terjadi fluktusi perolehan skor selama tahun-tahun tersebut.

Profile risiko financial perbankan pada Bank Nagari untuk tahun 2015-2020 adalah sebagai berikut:

Tabel 3. Profile risiko Bank Nagari tahun 2015-2020

\begin{tabular}{|c|c|c|c|c|c|}
\hline Risiko Finansial & 2015 & 2016 & 2017 & 2018 & 2019 \\
\hline 1. Risiko Kredit & 173 & 230 & 262 & 230 & 221 \\
\hline 2. Risiko Pasar & 100 & 100 & 100 & 144 & 147 \\
\hline 3. Risiko Operasional & 215 & 177 & 240 & 231 & 277 \\
\hline 4. Risiko Likuiditas & 325 & 250 & 250 & 207 & 227 \\
\hline
\end{tabular}

Sumber: Data Sekunder Bank Nagari Tahun 2008-2012

Keterangan:

1. $100-<180=1$ (Low) "Hampir tidak mungkin terjadi"

2. $180-<260=2$ (Low to moderate) "Kemungkinan kecil terjadi"

3. $260-<340=3$ (Moderate) "Dapat terjadi atau tidak dapat terjadi 50:50"

4. $340-<420=4$ (Moderate to high) "Besar kemungkinan terjadi"

5. $>420-500=5$ (High) "hampir pasti terjadi"

Sumber: SE 13/24/DPNP/25 Okt 2011

Tabel 3 di atas adalah data yang digunakan dalam penelitian ini yang bersifat interval. Data-data tersebut merupakan nilai masing-masing dimensi risiko finansial yang sudah dikalikan dengan bobot yang sudah ditetapkan untuk setiap indikator pada masing-masing dimensi. Untuk indikator risiko kredit pada tahun 2015 sampai 2019 mengalami fluktuasi dengan peringkat "low to moderate" yang berarti kemungkinan terjadinya risiko kredit pada Bank Nagari tergolong kecil, namun pada tahun 2017 risiko kredit mencapai angka 262 dengan peringkat "moderate" yang berarti bahwa risiko ini mungkin dapat terjadi atau mungkin tidak dapat terjadi atau peluang terjadinya (50:50). Peningkatan trend pada indikator kredit dapat diperkirakan oleh terkonsentrasinya penyediaan dana pada debitur, wilayah geografis, produk, jenis pembiayaan atau lapangan usaha tertentu.

\section{Pengujian Hipotesis dan Pembahasan}

Penelitian ini menggunakan data sekunder dari Bank Nagari yang terdiri dari tahun 2015 sampai tahun 2019. Data yang diperoleh berupa Laporan Tahunan, Kesimpulan GCG, dan Profil Risiko Bank Nagari. Dalam pengujian hipotesis pada penelitian ini menggunakan analisis koefisien korelasi rank spearman. Adapun variabel yang diteliti dalam penelitian ini adalah variabel GCG dan variabel risiko finansial pada Bank Nagari. 
Tabel 4. Output SPSS

Correlations

\begin{tabular}{|lll|r|r|}
\hline & & Rank of sum & Rank of GCG \\
\hline Spearman's rho & Rank of sum Correlation Coefficient & 1.000 & $.900^{*}$ \\
& & & .037 \\
& Sig. (2-tailed) & 5 & 5 \\
\cline { 2 - 4 } & $\mathrm{N}$ & $.900^{*}$ & 1.000 \\
\cline { 2 - 5 } & Rank of GCG Correlation Coefficient & .037 & 5 \\
& Sig. (2-tailed) & 5 & 5 \\
& $\mathrm{~N}$ & & 5 \\
\hline
\end{tabular}

*. Correlation is significant at the 0.05 level (2-tailed).

Dari tabel $4 \mathrm{di}$ atas menunjukan bahwa Korelasi Rank Spearman didapatkan nilai koefisien korelasi sebesar 0,900 dengan signifikansi 0,037. Koefisien tersebut mendekati nilai 1 (satu), maka dapat disimpulkan bahwa hubungan antara penerapan GCG dengan Risiko Finansial Perbankan pada Bank Nagari adalah tinggi sekali/kuat sekali/dapat diandalkan.

Nilai signifikansi 0,037 <0,05, sehingga dapat disimpulkan terjadi hubungan yang signifikan antara penerapan GCG dengan Risiko Finansial Perbankan pada Bank Nagari. Tanda bintang satu menunjukan bahwa korelasi signifikan pada level 0,05. Angka koefisien positif menunjukan hubungan positif. Jika penerapan GCG di Bank Nagari semakin baik, maka risiko finansial juga semakin dapat diminimalisir. Nilai 2-tailed menunjukan pengujian 2 (dua) sisi, yaitu sisi positif dan sisi negatif. Sedangkan nilai N menunjukan jumlah data dalam penelitian ini berjumlah 5 (lima)/ 5 tahun.

\section{Interprestasi Hasil Penelitian}

Hasil analisis korelasi atas pengujian hipotesis dengan variabel bebas good corporate governance (GCG) dan Risiko finansial perbankan sebagai variabel terikat dapat dilihat pada tabel di atas. Penjelasan yang dapat diberikan berkaitan dengan hasil model tersebut adalah bahwa penerapan good corporate governance yang diukur dengan 11 indikator berdasarkan Peraturan Bank Indonesia No. 8/14/PBI/2006 tentang Penerapan Good Corporate Governance Bagi Umum berhubungan secara signifikan dengan risiko finansial sesuai dengan Peraturan Bank Indonesia No.5/8/PBI/2003 tentang Penerapan Manajemen Risiko bagi Bank Umum pada Bank Nagari. Dengan demikian maka dapat disimpulkan Hipotesis Ho ditolak. Hasil koefisien korelasi senilai 0,900 memiliki arti bahwa hubungan antara penerapan good corporate governance (GCG) dengan risiko finansial perbankan sangat tinggi/kuat sekali. Tanda korelasi yang positif menunjukan bahwa semakin baik penerapan GCG pada Bank Nagari maka, risiko finansial semakin terkontrol atau semakin dapat diminimalisir.

Pelaksanaan GCG pada Bank Nagari senantiasa berlandaskan pada lima prinsip yaitu Transparansi (keterbukaan dalam mengemukakan informasi yang material dan relevan serta keterbukaan dalam proses pengambilan keputusan), Akuntabilitas (kejelasan fungsi dan pelaksanaan pertanggungjawaban organ bank sehingga pengelolaannya berjalan secara efektif, Pertanggungjawaban (kesesuaian pengelolaan bank dengan peraturan perundang-undangan yang berlaku dan prinsip-prinsip pengelolaan bank yang sehat, Indepedensi (pengelolaan bank secara profesional tanpa pengaruh/tekanan dari pihak manapun. Kewajaran (adil dan kesetaraan dalam memenuhi hak-hak stakeholders yang timbul berdasarkan perjanjian dan undang-undang yang berlaku). Dalam menerapkan kelima prinsip tersebut Bank Nagari berpedoman pada berbagai ketentuan dan peraturan perundang-undangan yang berlaku yang terkait dengan pelaksaan GCG sehingga penerapan yang dilakukan oleh Bank Nagari terhadap GCG mengalami peningkatan. Walaupun secara umum Bank Nagari telah memperoleh peringkat Baik mulai dari tahun 2015-2019 
namun nilai maksimal belum bisa diraih karena masih terdapat kelemahan dan masih diperlukan beberapa perbaikan untuk memperkuat kondisi internal Bank sehingga nantinya risiko finansial pada Bank Nagari secara otomatis dapat dikurangi menjadi serendah-rendahnya.

Keberhasilan penerapan GCG dalam mengurangi risiko finansial perbankan yang sejalan dengan teori yang sudah ada dan sesuai dengan tujuan diterapkannya GCG pada bank umum. Penerapan GCG mampu mengurangi risiko finansial perbankan karena faktor-faktor penerapan GCG yang dikembangkan oleh Bank Indonesia sangat memperhatikan prinsip Prudential dimana salah satu faktor penerapan GCG adalah pembentukan Komitte pemantau risiko yang berada di bawah Direksi yang bertugas untuk melakukan evaluasi kebijakan manajemen risiko, melakukan evaluasi tentang kesesuaian antara kebijakan manajemen risiko dengan pelaksanaan kebijakan tersebut dan melaksanakan evaluasi pelaksanaan tugas komitte Manajemen Risiko dan Satuan Kerja Manajemen Risiko. Penerapan Manajemen Risiko inilah yang kemudian secara teori mampu mereduksi risiko finansial pada Bank Nagari, ditambah pula dengan diterapkannya audit intern dan ekstern juga turut berkontribusi dalam keberhasilan GCG mengurangi risiko finansial.

Selain itu, dalam pelaksanaan GCG yang bertujuan untuk memperkuat kondisi internal Bank Nagari yang sejalan dengan pengelolaan risiko finansial juga diperlukan keberadaan Komisaris Independen dan Pihak Independen. Keberadaan pihak-pihak independen tersebut dapat menciptakan check dan balance, menghindari benturan kepentingan dalam pelaksanaan tugasnya serta melindungi kepentingan stakeholders khususnya pemilik dana. Jika hal tersebut dijalankan dengan baik, maka banyak keuntungan yang dapat diperoleh Bank Nagari yaitu selain kuatnya pertumbuhan kondisi bank juga semakin baik risiko-risiko yang akan dihadapi dikemudian hari.

\section{Kesimpulan Dan Saran}

Penelitian ini bertujuan untuk melihat hubungan antara penerapan good corporate governance (GCG) dengan risiko finansial perbankan pada Bank Nagari Kantor Pusat pada tahun 2015-2019. Hasil penelitian yang dilakukan menunjukan bahwa penerapan GCG berhubungan kuat dengan risiko finansial perbankan dilihat dari hasil output SPSS dengan nilai koefisien korelasi (KK) sebesar 0,900 dan nilai signifikan sebesar 0,037 $(<0,05)$. Hasil tersebut menunjukan bahwa keberhasilan penerapan GCG dalam mengurangi risiko finansial perbankan pada Bank Nagari sejalan dengan teori yang sudah ada dan sesuai dengan tujuan diterapkannya GCG pada bank umum. Penerapan GCG mampu mengurangi risiko finansial perbankan karena faktor-faktor penerapan GCG yang dikembangkan oleh Bank Indonesia sangat memperhatikan prinsip Prudential dimana salah satu faktor penerapan GCG adalah pembentukan Komitte pemantau risiko yang berada di bawah Direksi yang bertugas untuk melakukan evaluasi kebijakan manajemen risiko, melakukan evaluasi tentang kesesuaian antara kebijakan manajemen risiko dengan pelaksanaan kebijakan tersebut dan melaksanakan evaluasi pelaksanaan tugas komitte Manajemen Risiko dan Satuan Kerja Manajemen Risiko. Penerapan Manajemen Risiko inilah yang kemudian secara teori mampu mereduksi risiko finansial pada Bank Nagari, ditambah pula dengan diterapkannya audit intern dan ekstern juga turut berkontribusi dalam keberhasilan GCG mengurangi risiko finansial.

\section{Referensi}

Idroes, Ferry N, 2016, Manajemen Risiko Perbankan (Pemahaman Pendekatan 3 Pilar Kesepakatan Basel II Terkait Aplikasi Regulasi dan Pelaksanaannya di Indonesia), PT Rajagrafindo Persada, Jakarta.

Sari, Irmala, 2017, Pengaruh Mekanisme Good Corporate Governance terhadap Kinerja Perbankan, Skripsi, FE Universitas Diponogoro, Semarang. 
Hasan, Iqbal,MM, 2016, Pokok-Pokok Materi Statistik 2 (Statistik Inferensif) Edisi Kedua, PT. Bumi Aksara, Jakarta.

Harahap. Sofyan. Syafri. 2011. Teori Akuntansi. Edisi Revisi. PT RajaGrafindo Persada. Jakarta.

Peraturan Bank Indonesia Nomor 5/8/PBI/2003 Tentang Penerapan Manajemen Risiko Bagi Bank Umum.

Peraturan Bank Indonesia Nomor 2/27/PBI/2003 Tentang Bank Umum.

Peraturan Bank Indonesia Nomor 8/14/PBI/2006 Tentang Pelaksanaan Good Corporate Governance Bagi Bank Umum.

SE. Nomor 5/21/DPNP Perihal Penerapan Manajemen Risiko bagi Bank Umum.

SE. Nomor 9/12/DPNP Perihal Pelaksanaan Good Corporate Governance bagi Bank Umum dan Lampiran.

SE. Nomor 5/21/DPNP Perihal Penilaian Tingkat Kesehatan Bank Umum. Laporan Tahunan Bank Nagari tahun 2015-2019.

Profile Risiko Bank Nagari tahun 2015-2019. 